\title{
Historical museum specimens reveal the loss of genetic and morphological diversity due to local extinctions in the endangered water chestnut Trapa natans L. (Lythraceae) from the southern Alpine lake area
}

\author{
DAVID FREY ${ }^{1,2,3,4 *}$, CHRISTOPH REISCH ${ }^{5}$, BARBARA NARDUZZI-WICHT ${ }^{6}$, \\ EVA-MARIA BAUR ${ }^{5}$, CAROLINA CORNEJO ${ }^{2}$, MASSIMO ALESSI ${ }^{1,7}$ and \\ NICOLA SCHOENENBERGER ${ }^{1}$
}

\author{
${ }^{1}$ Natural History Museum of the Canton Ticino, Viale C. Cattaneo 4, 6900 Lugano, Switzerland \\ ${ }^{2}$ Swiss Federal Research Institute WSL, Biodiversity and Conservation Biology, Zürcherstrasse 111, 8903 \\ Birmensdorf, Switzerland \\ ${ }^{3}$ Institute of Terrestrial Ecosystems, ETH Zurich, Universitätsstrasse 16, 8092 Zürich, Switzerland \\ ${ }^{4}$ Botanical Museum of the University of Zurich, Zollikerstrasse 107, 8008 Zürich, Switzerland \\ ${ }^{5}$ Institute of Plant Sciences, University of Regensburg, Universitätsstrasse 31, 93053 Regensburg, \\ Germany \\ ${ }^{6}$ Laboratory of Applied Microbiology, DECD, SUPSI, Via Mirasole 22a, 6500 Bellinzona, Switzerland \\ ${ }^{7}$ Department of Biotechnology and Biosciences, University of Milano-Bicocca, Piazza della Scienza, 2, \\ 20126 Milano, Italy
}

Received 21 December 2016; revised 22 June 2017; accepted for publication 14 August 2017

\begin{abstract}
Freshwater aquatic plants have increased extinction risks due to strong human pressure and the patchy nature of their habitats. However, their unclear population structure frequently hinders conservation planning. To investigate population subdivision and risks to long-term survival of such species, we combined genetic, morphometric and biogeographical approaches to the example of the endangered water chestnut Trapa natans (Lythraceae) from the southern Alpine lake area (Insubria). Amplified fragment length polymorphism (AFLP) of seven extant local stands revealed similar and intermediate levels of genetic diversity, of which c. $97 \%$ was partitioned within lakes. Thus, no signs of strong genetic drift and associated loss of genetic diversity were found, despite a reduction of $c$. $52 \%$ of local populations since the early 19th century. Nuclear ribosomal sequences (ITS1-5.8S rRNA-ITS2) combined with a morphometric study of nuts (based on fresh and historical museum material) revealed the presence of two genetically and morphologically slightly distinct lineages, one of which went extinct during the 20th century after a prolonged period of hyper-eutrophication. Taken together, our results indicate the current presence of one large Insubric Trapa population. To prevent genetic risks to survival associated with small population size and increasing fragmentation due to past extinctions, freshwater managers should preserve the large census sizes still present in many Insubric lakes and reduce eutrophication.
\end{abstract}

ADDITIONAL KEYWORDS: AFLP - conservation - genetic structure - Insubric region - internal transcribed spacer - multivariate morphometrics - phylogeny - Trapa muzzanensis - Trapa verbanensis.

\section{INTRODUCTION}

Aquatic vascular plants have a high conservation priority due to their important functions in freshwater ecosystems and the strong human pressure on their

*Corresponding author. E-mail: david.frey@wsl.ch habitat (e.g. Strayer \& Dudgeon, 2010). However, difficulties in delimiting populations and taxonomic uncertainties frequently hinder the quantification of population trends and assessment of risks to survival (Barrett, Eckert \& Husband, 1993; Kozlowski, 2008). Investigating their genetic diversity and population structure can contribute to defining conservation 
units, resolving taxonomic problems and elucidating demographic processes and genetic risks to long-term survival. Hence, such investigations are important for conservation planning (Ellstrand \& Elam, 1993; Frankham, Bradshaw \& Brook, 2014).

Population genetic studies of aquatic plants have recently experienced increased research interest in the context of biological invasions (Roman \& Darling, 2007), the conservation of rare and threatened species (e.g. Elansary, Adame \& Štorchová, 2010; Arrigo et al., 2011) and the investigation of genetic consequences of life-history traits (Eckert et al., 2003). However, they still receive less research attention than terrestrial plants (e.g. Reisch \& Bernhardt-Römermann, 2014).

Although aquatic plants vary in terms of their ecological niche, life-history traits and breeding system, most studies report low levels of genetic diversity within populations (e.g. Barrett et al., 1993; Santamaría, 2002). This finding is commonly attributed to clonal growth and low levels of sexual reproduction (Barrett et al., 1993; Santamaría, 2002). However, low genetic diversity within populations can also be due to a small effective population size, that is high levels of genetic drift (Barrett et al., 1993). High levels of genetic drift, with associated loss of genetic diversity, are expected especially in annual aquatic plants living in ephemeral habitats, where extinction and colonization events frequently occur (Barrett et al., 1993; Pannell \& Charlesworth, 2000).

In contrast to the consistently low genetic diversity in aquatic plant populations, genetic differentiation between populations is more variable: moderate to high genetic structure and genetic uniformity over large geographical distances have been found (e.g. Barrett et al., 1993; Santamaría, 2002; Elansary et al., 2010). Isolation-by-distance patterns, which are the correlations between genetic and geographic distance, vary, suggesting different levels of gene flow and genetic drift within and between populations (Barrett et al., 1993).

Human activities can shape the genetic diversity and structure of aquatic plant populations (Roman $\&$ Darling, 2007). On the one hand, anthropogenic destruction and degradation of aquatic habitats can reduce the size of local populations (i.e. demes) and may increase their extinction rates, leading to population fragmentation (e.g. Dudgeon et al., 2006). Such fragmentation adds to the already natural isolation of many local aquatic plant populations, caused by the discrete nature of their habitats. Population size reduction and isolation can lead not only to a loss of genetic diversity within demes but also to a higher genetic differentiation because effective population sizes and migration rates are lowered in small and isolated populations (e.g. Young, Boyle \& Brown, 1996; Mona et al., 2014). In contrast, human-mediated dispersal has enlarged the distribution range and population sizes of numerous aquatic plant species, with many of them classified as invasive organisms (e.g. Hussner, 2012). Human dispersal often leads to repeated introductions, which can increase gene flow between populations and thus decrease population differentiation (Roman \& Darling, 2007).

Here we study the genetic diversity and population structure of the water chestnut Trapa natans L. (Lythraceae) as an example of an annual aquatic plant of conservation concern. This species has been declining in Europe since at least the early 19th century (Jäggi, 1883; Hegi, 1926) and is now rare and regionally extinct (Lansdown, 2013). The causes of its decline are obscure, although they have been attributed to anthropogenic freshwater eutrophication and destruction (Lansdown, 2013). Moreover, the analysis of numerous sub-fossil fruits of Trapa L. showed that climatic oscillations in combination with natural habitat loss due to vegetation succession had already reduced its distribution range since the end of the Holocene thermal maximum (e.g. Gams, 1927; Apinis, 1967).

Assessing the conservation status and population trends in T. natans is complicated by the unresolved taxonomy: in Europe, up to 12 taxa have been described (Flerov, 1925; Vasilev, 1974). However, only T. natans is currently recognized as a species (Tutin, 1968; Lansdown, 2013; but see Tzvelev, 1993). The resulting uncertainty about species identities and numbers is an example of the Linnean shortfall and can lead to biased Red List classifications (Kozlowski, 2008).

The reason for the taxonomic uncertainty is the high level of morphological variability of fruits, on which species descriptions have been traditionally based, and the heterogeneous treatments of nut characters by different authors (e.g. Schinz, 1907; Flerov, 1926; Tzvelev, 1993; Takano \& Kadono, 2005). It is, however, unclear to what degree the variations in nut morphology reflect adaptive divergence between populations and/or species or whether they are only an expression of phenotypic plasticity (Tutin, 1968; Takano \& Kadono, 2005).

So far, the few existing genetic studies on Trapa have investigated phylogenetic relationships within Lythraceae and Myrtales (e.g. Conti et al., 1997). Hoque, Anai \& Arima (2005) and Kim, Na \& Choi (2010) established protocols for investigating molecular diversity but did not attempt to conduct population genetic investigations or resolve taxonomic problems. At the population level, an investigation in Japan of isozyme variability in $T$. natans revealed reduced genetic variation within and between populations 
(Takano \& Kadono, 2005), whereas Li et al. (2017) found low genetic diversity and high genetic structure in three Asian Trapa spp. based on amplified fragment length polymorphisms (AFLP).

This lack of genetic investigations is surprising because T. natans is of economic and ethnobotanical interest: water chestnuts have been used since the Neolithic age as a food, medicinal and ornamental plant across Eurasia (e.g. Renfrew, 1973). Although considered a minor or a wild crop, the species is still cultivated today in parts of Asia, where it can locally assume a role for human nutrition (Hoque et al., 2009). Hence, it has long been recognized that many water chestnut stands originate from deliberate introductions: especially since the species is frequently found in artificial ponds (Hegi, 1926; Gams, 1927).

Here we focus on the water chestnuts of the southern Alpine lake area (Insubric region), which is located in southern Switzerland and northern Italy (Fig. 1). Insubric T. natans has long been recognized for its rich morphological variability (Schinz, 1907). Three major fruit types, which were formerly attributed to three different taxa, can be distinguished: the widespread T. natans, and the rare Trapa muzzanensis Jäggi and Trapa verbanensis De Not., which are restricted to the lakes Muzzano and Verbano, respectively (Schinz, 1907). First hypothesized to be local endemics, they were later also found in eastern Europe and northern Italy, respectively, in extant populations and in sub-fossil remains (e.g. Gams, 1927; Tzvelev, 1993; Ciocârlan, 2011). Such a high level of morphological variability of T. natans s.l. in a single region is unique in Europe (Gams, 1927), but it is not known whether these taxa should be recognized as different conservation units. The extant Insubric water chestnut stands are presumably the remains of a formerly vast system of local populations of which many disappeared during the 20th century. However, the extent to which local extinctions took place and how this affected their morphological and genetic diversity is not known.

The main aim of this contribution is to investigate the population structure and diversity of the Insubric

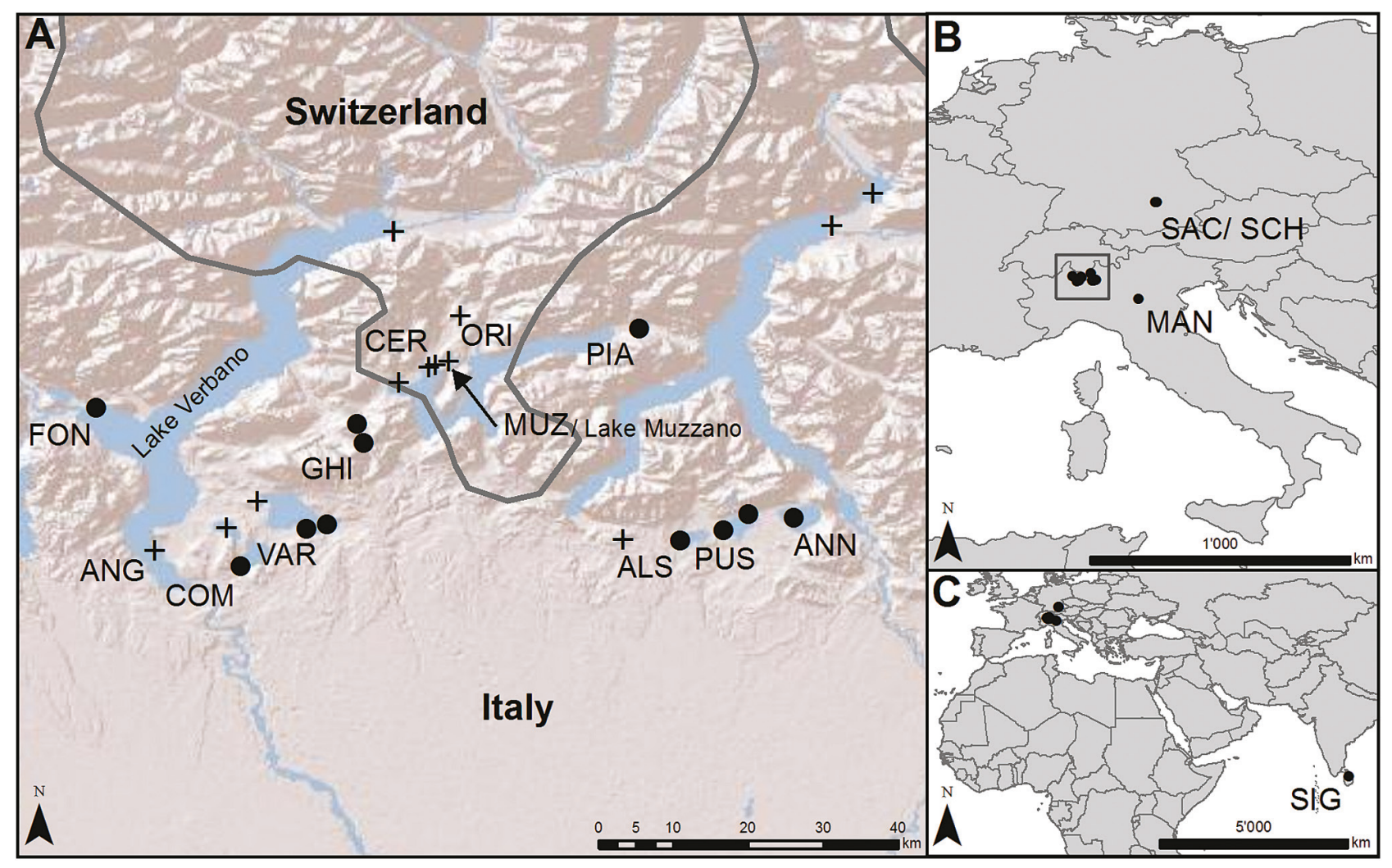

Figure 1. Sampling sites for genetic and morphometric analysis of Trapa natans (ALS, ANN, CER, COM, GHI, ORI, PIA, PUS, VAR), Trapa muzzanensis (MUZ) and Trapa verbanensis (ANG, FON) in the Insubric region (A). Subplot (B) indicates the sampling sites of T. natans from central Italy (MAN) and Germany (SAC, SCH) and subplot (C) the sampling site of T. natans from Sri Lanka (SIG). The filled circles indicate sites where Trapa currently occurs, and crosses indicate extinct stands, that is sites with former records (1824-1999) but absences verified by us in the field (2000-2013). Note that historical herbarium specimens and fruit collections were used to analyse the extinct populations both genetically and morphometrically. 
T. natans s.l. by using AFLPs (Vos et al., 1995). Specifically, we investigated genetic patterns of extinction-colonization dynamics and other signs of genetic drift and loss of genetic variation, which may threaten their long-term survival. In Trapa, AFLPs have been successfully applied to assess population genetic diversity and structure and to discriminate between closely related species (Li et al., 2017). Furthermore, by comparing current and historical distribution records, we attempt to retrace the distribution history of the species in the Insubric region since the beginning of the 19 th century. Finally, to elucidate phylogenetic position and define unambiguous conservation units, we used internal transcribed spacer (ITS1 and ITS2) and 5.8S ribosomal RNA sequences in combination with a morphometric study of fruits, with special attention to the doubtful T. muzzanensis and T. verbanensis. To achieve this, we used plant material sampled in the field and specimens from historical collections.

\section{MATERIAL AND METHODS}

\section{STUDY SPECIES}

Trapa natans is an annual, floating-leaved freshwater plant that inhabits mesotrophic to eutrophic, lowenergy water bodies (Tutin, 1968). It colonizes ponds, lakes, shallow bays and flood plains of low-elevation river systems, for example oxbow lakes. It grows on substrates rich in organic matter and at water depths between 1 and $3 \mathrm{~m}$ (Apinis, 1940, 1967).

The large native range of water chestnut spans the temperate and tropic zones of Eurasia and Africa (Gams, 1927). In contrast to its large range, it has a patchy distribution and is rare in some regions (Lansdown, 2013). It was deliberately introduced into Australia and North America, where it is now considered to be invasive due to its capacity to form large and dominant stands (Hummel \& Kiviat, 2004).

The life cycle of $T$. natans begins with a vigorous vegetative growth phase, during which a plant forms several rosettes: each bearing insect-pollinated, bisexual flowers (Kadono \& Schneider, 1986). The prevailing mating system appears to be self-fertilization (Kadono \& Schneider, 1986; Arima, Daigoho \& Hoque, 1999). After pollination, the flower stalk bends below the water surface. The petals and up to two sepals are then dropped. The remaining sepals harden during the development of the fruit, forming two, three or four horns (Arima et al., 1999). Each horn has a barbed hook at one end, which may favour animal dispersal. However, upon maturity, the fruits sink to the bottom of the water body and overwinter in the sediment. The fruit is a drupe with a soft, fleshy, green exocarp and contains one seed. During winter, the exocarp decomposes and reveals the hard and persistent endocarp (i.e. the nut) (Tutin, 1968).

\section{SAMPLING}

For genetic analysis, leaf material was collected from seven of the eight Insubric lakes that still harbour Trapa (Fig. 1; Table 1). To gain insight into larger scale patterns of genetic diversity, one central Italian population (Mantova), two German populations (Sachenbach and Scheyern) and one Sri Lankan population were also sampled (Table 1). In each sampling site, leaves from four to ten individuals were collected and dried in silica gel. Sampling of genetically identical plants (i.e. ramets) was avoided by maximizing distances between sampled rosettes. To include the extinct population that harboured the doubtful T. muzzanensis from lake Muzzano in the internal transcribed spacer (ITS) analysis, leaf material was retrieved from nine herbarium specimens that had been collected between 1874 and 1961 and deposited in the herbaria of the Natural History Museum of the Canton Ticino (LUG) or in the unified herbaria of the Swiss Federal Institute of Technology and the University of Zurich $(\mathrm{ZT}+\mathrm{Z})$ (Table 1; Supporting Information, Table S1).

The biometrical study of nuts was conducted with a total of 199 intact and germinated nuts (i.e. without the exocarp) collected in the field during the sampling of plant material for genetic analysis. To assess extinct populations and/or taxa from the Insubric region, specimens stored in ZT, Z and the Botanical Museum of the University of Zurich (ZM) (Supporting Information, Table S2) were included in the analysis. This approach yielded 49 nuts of T. muzzanensis (all from the unique Insubric population of Lake Muzzano, which is now extinct), 127 nuts of $T$. natans and 23 nuts of T. verbanensis (all from Lake Verbano, the only lake harbouring this nut-type; Supporting Information, Table S2). Note that 11 Insubric lakes (c. 65\%) that harboured Trapa since the beginning of the 18th century could be assessed. Voucher specimens and own nut collections were deposited in LUG.

\section{AMPLIFIED FRAGMENT LENGTH POLYMORPHISM}

DNA was extracted following the cetyl trimethylammonium bromide (CTAB) protocol (Rogers \& Bendich, 1994) with modifications (Reisch, 2007) and diluted in water to $7.8 \mathrm{ng} / \mu \mathrm{L}$. AFLPs were produced according to the protocol described in Reisch (2007) by using the three selective primer combinations M-CTG/E-AGC, M-CAA/E-AGG and M-CTG/E-ACT. AFLP fragments were scored with Bionumerics 6.6 (Applied Maths, Kortrijk, Belgium). Samples yielding no clear banding pattern or representing PCR artefacts were repeated, 


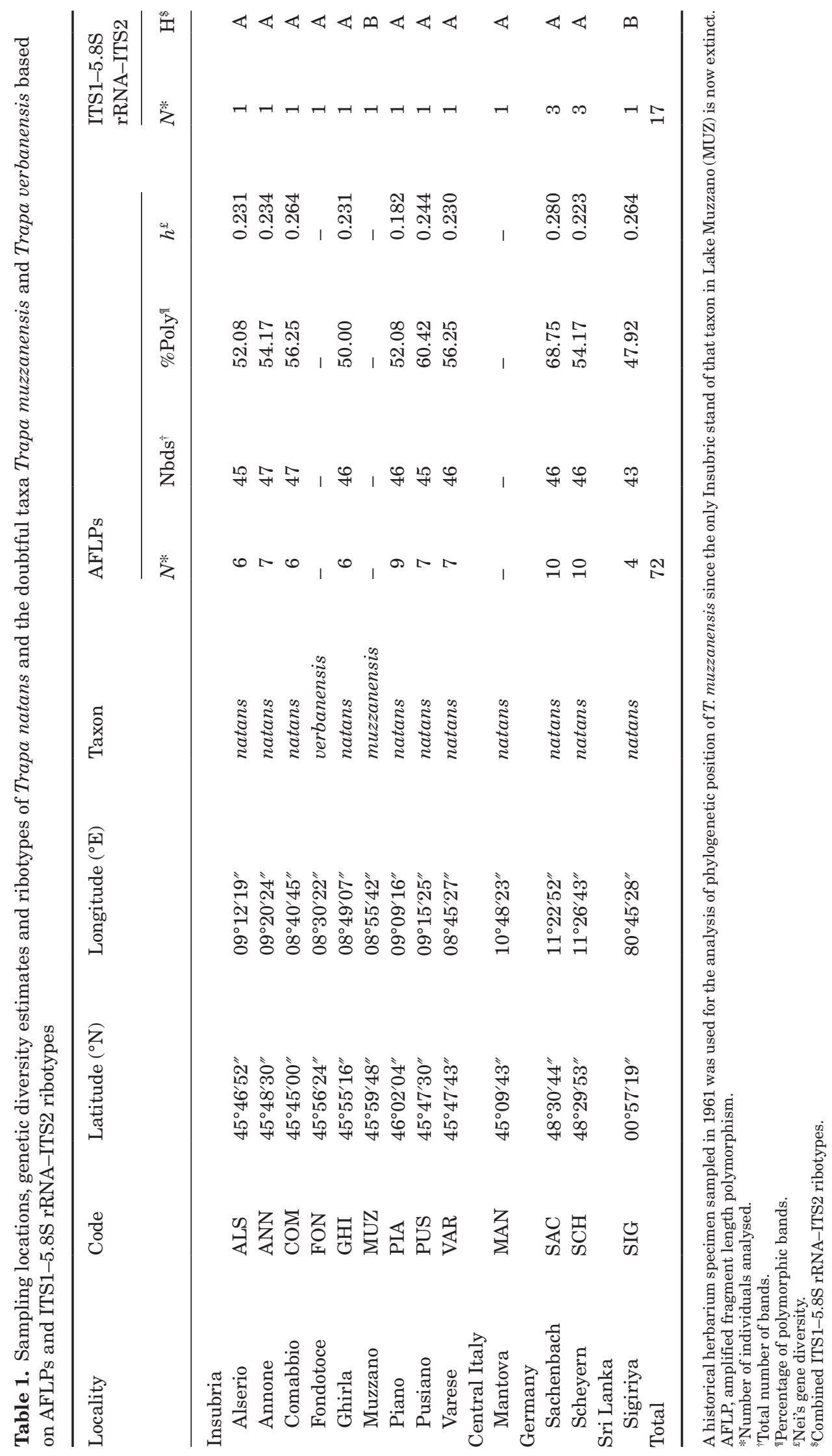


and 15 samples were excluded from the analysis due to weak and ambiguous banding patterns. Reproducibility of the AFLP profiles was assessed with $10 \%$ of the samples, which revealed an error rate of $2.3 \%$ (Bonin et al., 2004). Only polymorphic markers were used in the statistical analyses (Nybom, 2004). As a measure of genetic diversity within sampling sites, the proportion of polymorphic loci and Nei's gene diversity (Nei, 1987) were calculated using the 'AFLPdat' script (Ehrich, 2006) in the $\mathrm{R}$ environment ( $\mathrm{R}$ Core Team, 2014). Additionally, the number of private alleles was counted. Genetic structure was assessed with a neighbor-joining (NJ) cluster algorithm based on Jaccard's index of similarity among individuals. To estimate the genetic relatedness among the sampling locations, an NJ cluster algorithm was performed with Euclidian distances computed from allele frequencies of sampling locations. In both unrooted NJ trees, statistical support of nodes was assessed by 1000 bootstrap replicates. Analysis of molecular variance (AMOVA; Excoffier, Smouse \& Quattro, 1992) was performed to partition the genetic variance within and between (1) Insubric sites, (2) Insubric and German sites, (3) European sites and (4) the Sri Lankan sampling location. The significance of results was tested with 2000 replications. All analyses were performed in $\mathrm{R}$ using the 'ade4' and 'ape' packages (Chessel, Dufour \& Thioulouse, 2004; Paradis, Claude \& Strimmer, 2004). Finally, the genetic structure was evaluated with the Bayesian clustering algorithm implemented in the software STRUCTURE 2.3.3 (Pritchard, Stephens \& Donnelly, 2000). We ran STRUCTURE for 900000 iterations following a burnin period of 10000 iterations using the default values. To identify the most likely number of clusters using the method of Evanno, Regnaut \& Goudet (2005), Markov chain Monte Carlo estimates of ten replicate chains of $K$ from one to ten were obtained.

\section{HISTORICAL DISTRIBUTION}

Distribution records were collected from herbarium specimens and fruit collections (herbarium codes: FI, LUG, MSNM, ZM, ZT, Z), the Swiss National Flora Databank (Info Flora, 2014) and during a field survey of all 24 Insubric lakes between 2011 and 2013. Furthermore, the following literature on the Insubric flora was screened for distribution records: Comolli (1824, 1834), De Notaris (1876), Arcangeli (1882), Jäggi (1883), Franzoni (1888), Schröter (1899), Schinz (1907), Chenevard (1910), Voigt (1921), Steiner (1912) and Hegi (1926). Distribution records were considered only when they provided unambiguous information about sampling dates and sites. In addition, only one record per year and site was considered in the analysis. In lakes with more than one water chestnut stand, two sites were distinguished when they were $>1 \mathrm{~km}$ apart.
Extinction events were defined as sites with former records (1824-1999), but with absences between 2000 and 2013, as verified in the field. Georeferenced distribution records and extinction events were mapped with ArcGIS (version 10.2; ESRI).

\section{INTERNAL TRANSCRIBED SPACER SEQUENCING}

DNA was extracted using the DNeasy Plant Mini Kit (Quiagen) following the manufacturer's instructions. The DNA of the herbarium specimens of T. muzzanensis (Supporting Information, Table S1) was extracted following the CTAB protocol (Rogers \& Bendich, 1994). The ITS1-5.8S rRNA-ITS2 region was amplified using ITS4 and ITS5 primers (White et al., 1990) in a $50 \mu \mathrm{L}$ total volume with $25 \mu \mathrm{L}$ master mix, $10 \mu \mathrm{M}$ each primer, $5 \mu \mathrm{L}$ template DNA and water. The PCR was programmed for an initial denaturation step at $95{ }^{\circ} \mathrm{C}$ for $5 \mathrm{~min}$; 35 amplification cycles (1 min at $94{ }^{\circ} \mathrm{C}, 1 \mathrm{~min}$ at $50{ }^{\circ} \mathrm{C}, 2 \mathrm{~min}$ at $72{ }^{\circ} \mathrm{C}$ ) and a final step at $72{ }^{\circ} \mathrm{C}$ for $5 \mathrm{~min}$. As PCR amplification first failed with the herbarium specimens, internal primers TraIFor (5'-AATTGCAGAATCCCGTGAAC-3') and TraIRev (5'-GGGATTCTGCAATTCACACC-3') were designed using Primer3 0.4 .0 software (www. simgene.com; Untergasser et al., 2012). The thermal profile for internal primers consisted of one cycle at $95{ }^{\circ} \mathrm{C}$ for $15 \mathrm{~min}$; 35 cycles at $95{ }^{\circ} \mathrm{C}$ for $1 \mathrm{~min}, 50{ }^{\circ} \mathrm{C}$ for $1 \mathrm{~min}$ and $72^{\circ} \mathrm{C}$ for $1 \mathrm{~min}$; and a final cycle at $72{ }^{\circ} \mathrm{C}$ for $10 \mathrm{~min}$. Fragments were visualized on $0.8 \%$ agarose gel stained with GelRed and purified with Sephadex G100. Sequencing was performed by Microsynt (Balgach, Switzerland), and sequences were corrected and aligned using MEGA 6 (Tamura et al., 2013). Putative pseudogenes were investigated by screening for the presence of the three conserved motives M1 (5'-CGATGAAGAACGTAGC-3'), M2 (5'-GAATTGCAGAATCC-3') and M3 (in the 5.8s rRNA sequence (5'-TTTGAACGCA-3') (Hřibová et al., 2011).

The best-fit substitution model was selected with the software jModelTest 2.1.10 (Darriba et al., 2012). We ran 88 models in jModelTest, including 11 substitution schemes; equal or unequal base frequencies $(+\mathrm{F})$; a proportion of invariable sites $(+\mathrm{I})$; and rate variation among sites with several rate categories $(+G)$. The maximum likelihood (ML) option was used to compute base trees for each model, and the best model was selected based on the corrected Akaike information criterion (Akaike, 1973).

An unrooted ML tree was constructed using PhyML 3.0 (Guindon et al., 2010). Analyses were run on the ATGC bioinformatics server (atgc-montpellier.fr), allowing for the application of different substitution models. PhyML systematically treats gaps as unknown characters so the likelihood at these sites is summed over all the possible states that could be observed at each position (Guindon, 2009). To prevent an interruption 
of the calculation in a local maximum of the likelihood function, five random trees were employed as starting trees, which were estimated using the BioNJ algorithm (Gascuel, 1997). Support for internal branches was calculated using the nonparametric bootstrap option with 1000 replicates. An ML phylogram was drawn with TreeGraph 2.11.1-654_beta (Stöver \& Müller, 2010).

To illustrate the ribotypes and infer a gene genealogy, we constructed a ribotype network using the parsimony algorithm applied in TCS v.1.21 (Clement, Posada \& Crandall, 2000) with a 95\% connection limit and treating gaps as missing data. To elucidate the phylogenetic position of Insubric Trapa samples, ITS sequences from GenBank of all available water chestnut taxa were included in the phylogenetic analysis. The ITS sequences obtained in this study were deposited in GenBank (accession numbers KX098565-KX098577).

\section{MORPHOMETRICS}

Fourteen traits were chosen based on Kadono (1987), including characteristics to discriminate between T. natans and the doubtful taxa T. muzzanensis and T. verbanensis (Schinz, 1907; Flerov, 1926) (Table 2). Characteristics that did not vary between individuals were excluded from the analysis. We performed a principal component analysis (PCA) to visualize the morphological relationships among nuts, sampling sites and taxa, using the 'ade4' package implemented in R (Chessel et al., 2004). Confidence ellipses delineating the phenotypic spaces of the three taxa were constructed using the gravity centre with 1.5 SD.
Descriptive statistics of quantitative characters (mean, $\mathrm{SD}$, minimum, maximum and 5 and $95 \%$ percentiles) were computed for each taxon and each sampling site separately (Supporting Information, Table S3).

\section{RESULTS}

\section{AMPLIFIED FRAGMENT LENGTH POLYMORPHISM}

The three primer combinations generated 48 (33.6\%) polymorphic markers from 143 fragments. Variance in genetic diversity was low among sampling sites (mean \pm SD percentage of polymorphic markers: $55.2 \pm 5.7$; mean \pm SD Nei's gene diversity: $0.238 \pm 0.026$ ) Only one private allele was found (at the ALS sampling location). At the individual level, the NJ tree only showed significant clustering of the plants from Sri Lanka, but the genetic differences were small (Fig. 2A). At the level of sampling locations, the NJ tree revealed three clusters with bootstrap values $>50 \%$. Insubric sites were present in each cluster (Fig. 2B). According to AMOVA, most of the genetic variance $(31.5 \% ; P<0.001)$ was found between the European samples and the Sri Lankan samples (Table 3). AMOVA further revealed low genetic differentiation between Insubric sampling locations and no genetic differentiation was detected between Insubric and German sites (Table 3). Bayesian clustering analysis conducted with STRUCTURE indicated that the most likely number of genetic clusters $(K)$ was four (Supporting Information, Figs S1, S2). However, except for one genetic cluster mainly assigned to individuals from Sri Lanka, the remaining genetic clusters were

Table 2. Variables used for the morphometric analysis of nuts (i.e. endocarp) of Trapa natans, Trapa muzzanensis and Trapa verbanensis

\begin{tabular}{ll}
\hline Abbreviation & Variable \\
\hline Continuous quantitative characters \\
HN & Height of nut $(\mathrm{mm})$ : measured between base of nut and highest part of the coronary disc \\
HNE & Height of neck $(\mathrm{mm})$ : measured between base of neck and highest part of the coronary disc \\
WUH & Width across upper horns $(\mathrm{mm})$ \\
WC & Width of coronary disc $(\mathrm{mm}):$ mean of length and width of coronary disc \\
WUHB & Width of upper horn base $(\mathrm{mm}):$ mean of width of the two upper horn bases \\
WLH & Width across lower horns $(\mathrm{mm})$ \\
WLHB & Width of lower horn base $(\mathrm{mm}):$ mean of width of the two lower horn bases \\
TN & Thickness of nut $(\mathrm{mm}):$ measured without horn base \\
TNE & Thickness of neck $(\mathrm{mm}):$ mean of length and width of neck \\
Discrete quantitative characters & Number of upper horns \\
NUH* & Number of lower horns \\
NLH & \\
Binary characters & Tubercles between horns present (1) or absent (0) \\
T & Coronary disc or prominent edge around neck present (1) or absent $(0)$ \\
C* & Form of horn: cordate (1) or triangular $(0)$ \\
F &
\end{tabular}

*These characters were excluded from the analysis because they did not vary among individuals. 

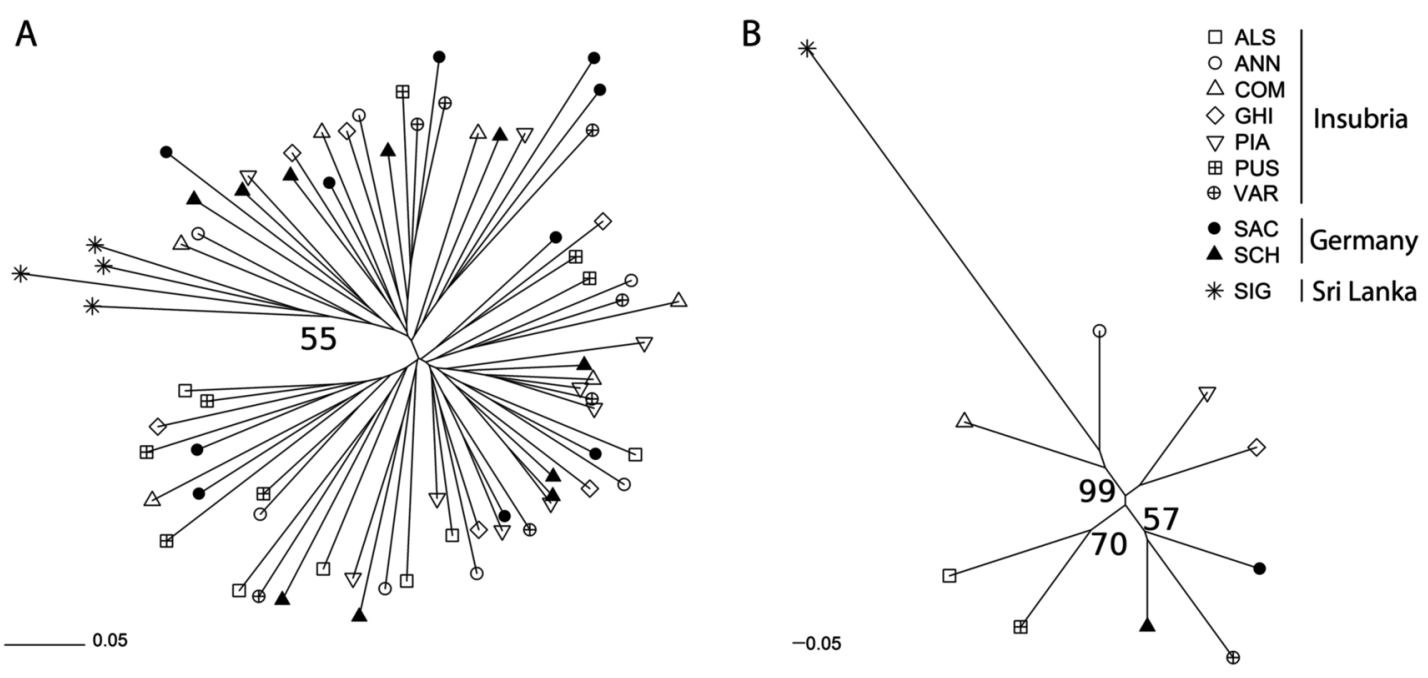

Figure 2. Unrooted neighbor-joining tree computed from AFLP data of (A) 72 Trapa natans individuals based on Jaccard's distances and (B) 10 T. natans populations based on Euclidian distances of allele frequencies. Bootstrap values $>50 \%$ computed by 1000 replicates are given.

Table 3. AMOVA of Trapa natans based on AFLP data considering (A) Insubric populations, (B) German and Insubric populations and (C) European populations and the Asian population from Sri Lanka

\begin{tabular}{|c|c|c|c|c|c|}
\hline Source of variance & d.f. & Sums of squares & Mean square & Variance components & $\%$ total variance \\
\hline \multicolumn{6}{|l|}{ (A) Insubria } \\
\hline Among sites & 6 & 0.947 & 0.158 & 0.00142 & $3.1^{*}$ \\
\hline Within sites & 41 & 5.318 & 0.130 & 0.12970 & 96.9 \\
\hline Total & 47 & 6.265 & 0.133 & 0.13382 & \\
\hline \multicolumn{6}{|c|}{ (B) Insubria and Germany } \\
\hline Among sites & 1 & 0.176 & 0.177 & 0.00144 & $1.2^{\mathrm{NS}}$ \\
\hline Within sites & 66 & 8.975 & 0.136 & 0.13599 & 98.8 \\
\hline Total & 67 & 9.152 & 0.137 & 0.13743 & \\
\hline \multicolumn{6}{|l|}{ (C) Europe and Asia } \\
\hline Among sites & 1 & 0.615 & 0.615 & 0.06317 & $31.5^{* * *}$ \\
\hline Within sites & 70 & 9.616 & 0.137 & 0.13737 & 68.5 \\
\hline Total & 71 & 10.231 & 0.144 & 0.20055 & \\
\hline
\end{tabular}

AFLP, amplified fragment length polymorphism; AMOVA, analysis of molecular variance; NS, not significant.

$* P<0.05$.

$* * * P<0.001$

present in almost all individuals and sampling sites from Europe. Other than the population of Sri Lanka, only the samples from the Insubric lakes Alserio (ALS) and Pusiano (PUS) showed a slight divergence both in the NJ of populations (Fig. 2B) and in the STRUCTURE analysis (Supporting Information, Fig. S2).

\section{DISTRIBUTION}

Out of 177 distribution records, 132 were retained for analysis after the removal of duplicates and ambiguous records. The analysed records had the following origin: literature $(N=51)$, herbaria and fruit collections $(N=40)$, the field survey $(N=28)$ and Info Flora databank $(N=13)$. Data covered a period of 189 years (1824-2013) and consisted of 98 presence and 34 absence records. During that period, the presence of T. natans s.l. was reported from 23 sites and from 17 lakes (c. $70 \%$ of all Insubric lakes). By the period from 2000 to 2013, c. $52 \%$ of the water chestnuts stands that were documented between 1824 and 2000 had disappeared (Fig. 1). Distribution records and habitat characteristics of the extinct and current stands are given in Supporting Information, Table S4. 


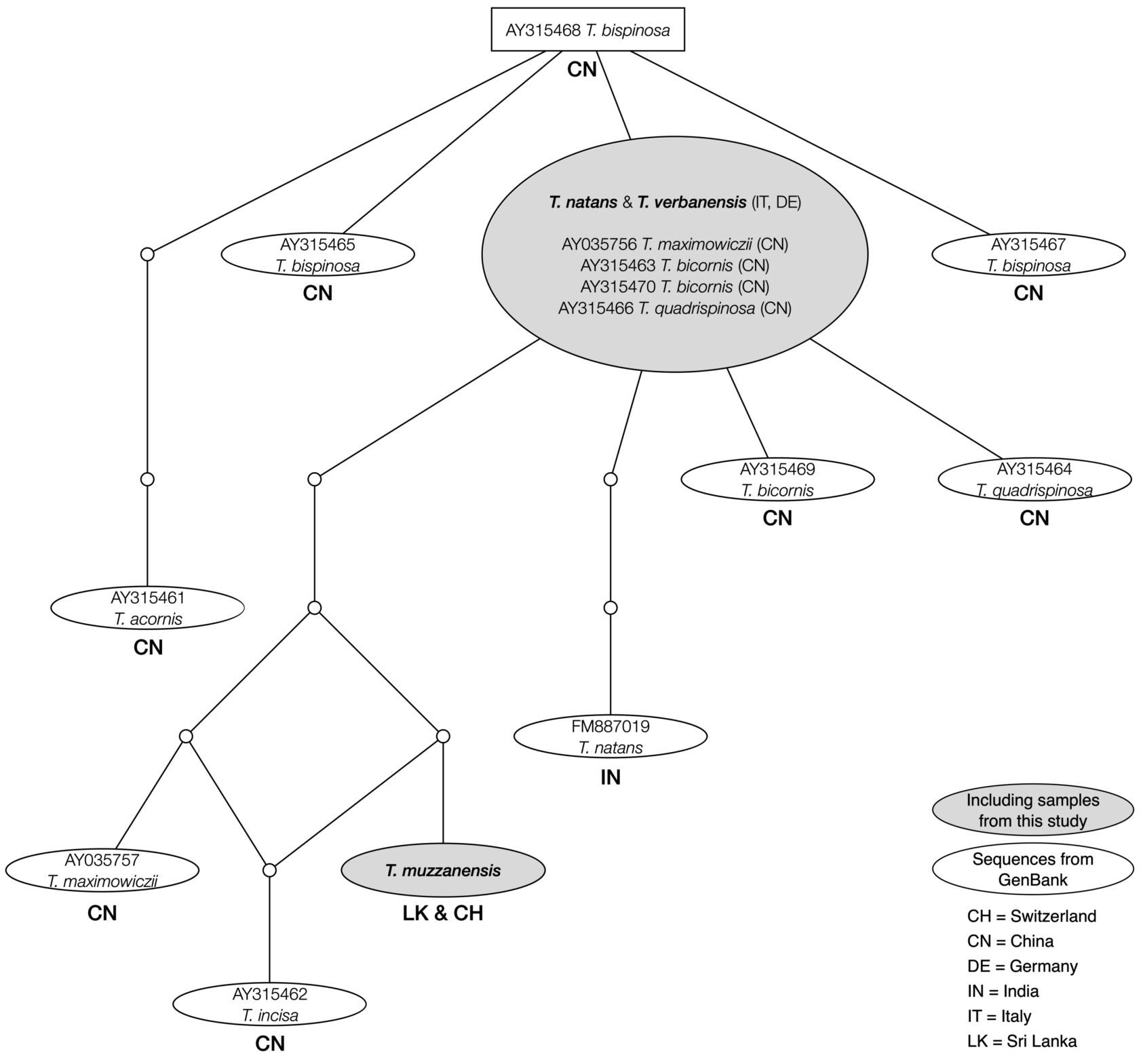

Figure 3. Ribotype network based on 623 bp of ITS1 (partial), 5.8S rRNA (complete) and ITS2 (partial) sequences. Note that the size of each ribotype is proportional to the number of individuals that share it.

INTERNAL TRANSCRIBED SPACER SEQUENCES

The ITS1 (partial), 5.8S rRNA (complete) and ITS2 (partial) sequences had a consensus alignment of 623 base pairs. The highly conserved motives M1, M2 and M3 were detected in all sequences, which indicate that no pseudogenes were present. Eight polymorphic sites were found, including four single nucleotide polymorphisms and four indels, which allowed for the identification of two distinct ribotypes (Table 1; Fig. 3; Supporting Information, Table S5). One ribotype was found only in a museum specimen collected in Lake Muzzano classified as T. muzzanensis, and in the T. natans sample from Sri Lanka. All other ribotypes were shared among the remaining samples. Trapa verbanensis did not have a distinct sequence. In the phylogenetic tree including all available ITS sequences of the genus Trapa, the extant Insubric samples clustered with German and central Italian samples and with reference sequences from China and India (Fig. 4). 


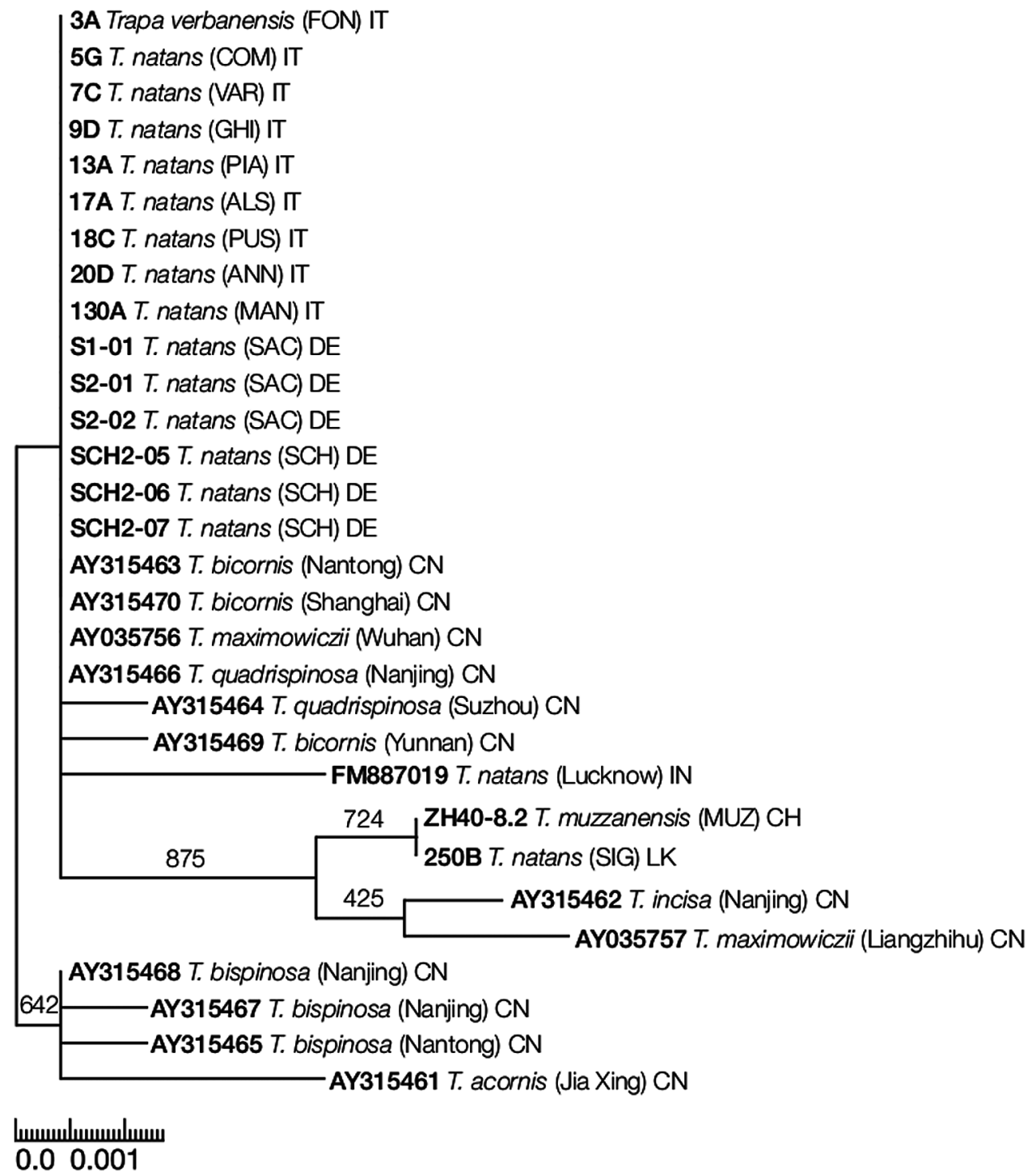

Figure 4. Unrooted maximum likelihood tree based on 623 bp of ITS1 (partial), 5.8S rRNA (complete) and ITS2 (partial) sequences. Support for internal branches was calculated by 1000 bootstrap replicates. Given are GenBank accession number, taxon, sampling site (in brackets) and country of origin $(\mathrm{CH}=$ Switzerland, $\mathrm{CN}=\mathrm{China}$, DE = Germany, IT = Italy, LK = Sri Lanka).

\section{MORPHOMETRICS}

The PCA did not separate T. muzzanensis and T. verbanensis from $T$. natans along the first axis, which explained $35.4 \%$ of the variability (Fig. 5A). Only the second PCA axis, which explained $21.9 \%$ of the variability, separated T. verbanensis nuts (Fig. 5A). Nuts of T. muzzanensis from Lake Muzzano clustered along the third axis, explaining $13.2 \%$ of the variation (Fig. 5B). The presence of 'tubercules' (Fig. 6A-E) between the horns in all but one sample from Lake Muzzano explained most of the variance (Supporting Information, Table S6). The traits contributing most to the separation of the T. verbanensis were associated with the two lower horns, which were consistently absent in samples from Lake Verbano (Fig. 6F-H).

\section{DISCUSSION}

\section{POPULATION GENETIC STRUCTURE AND DIVERSITY}

The AFLP analysis revealed similar and intermediate levels of genetic diversity within Insubric lakes, whereas the genetic differentiation between the lakes was low (Nybom, 2004; Reisch \& BernhardtRömermann, 2014; Tables 1 and 3; Fig. 5; Supporting Information, Figs S1, S2). Thus, no signs of strong genetic drift and associated loss of genetic diversity and increased genetic differentiation were found as in other annual aquatic plants or plants with a similar breeding system (e.g. Barrettet al., 1993; Nybom, 2004; Reisch \& Bernhardt-Römermann, 2014). This finding 

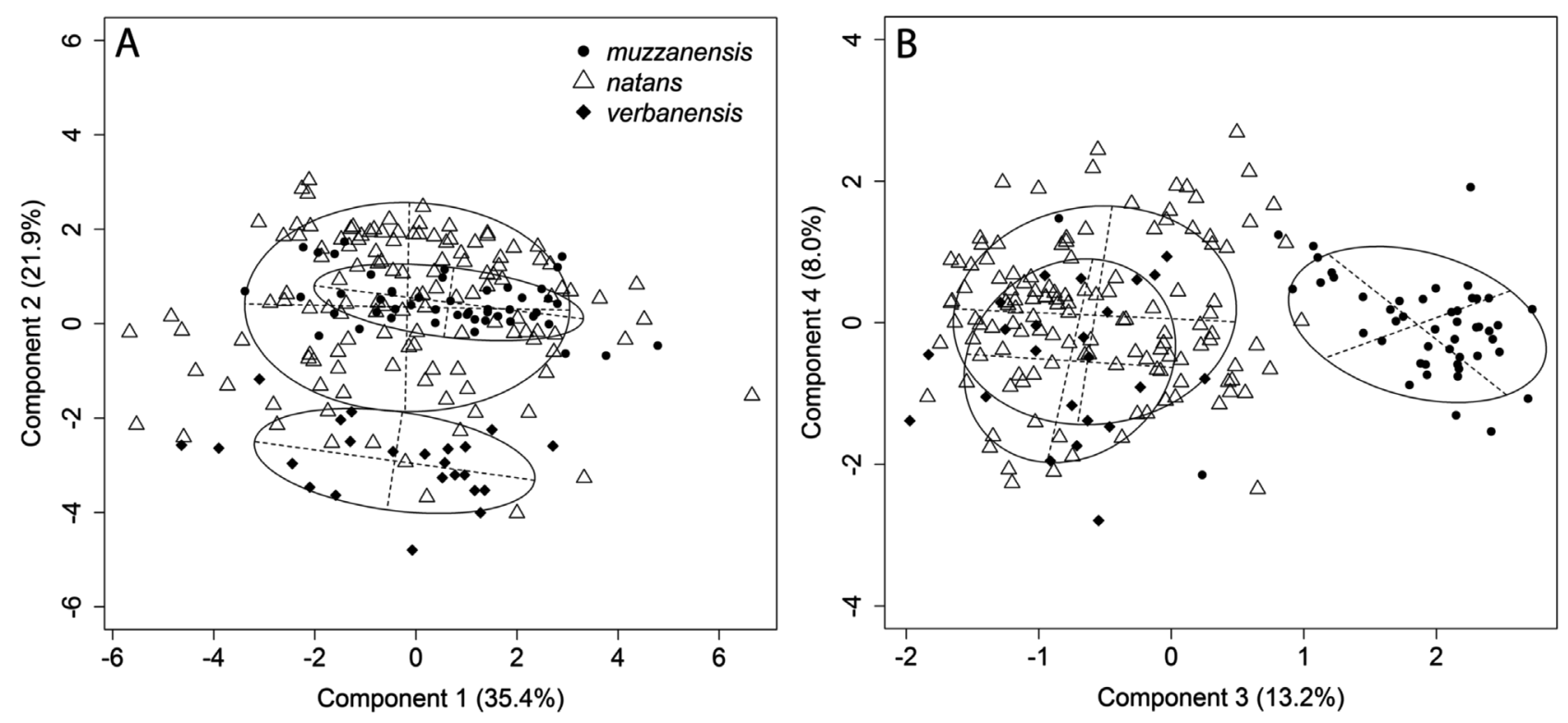

Figure 5. Principal component analysis plot of 12 morphological traits measured or scored in 199 Trapa nuts (i.e. the endocarp of the fruit). Symbols represent the three taxa distinguished in this study: triangles = Trapa natans, circles = Trapa muzzanensis and diamonds = Trapa verbanensis. Shown are (A) the first two principal components and (B) the principal components three and four and the proportion of variation explained by each. Ellipses indicate 1.5 SD around the gravity centre of each taxon.

agrees with the results of Takano \& Kadono (2005), who found reduced genetic differentiation between T. natans stands in Japan. This may be explained by three factors: (1) most extant Insubric Trapa stands have large census populations consisting of hundreds to thousands of individuals and dispose of seed banks (Hegi, 1926), which reduce the contemporary levels of genetic drift (e.g. Walser \& Haag, 2012); (2) Insubric water chestnuts are not subject to extinction-colonization dynamics as many other annual aquatic plants because they live in permanent water bodies. Hence, they do not show signs of reduced genetic diversity and increased genetic differentiation due to strong genetic drift caused by recurrent genetic bottlenecks (Barrett et al., 1993; McCauley, Raveill \& Antonovics, 1995; Nybom, 2004; Walser \& Haag, 2012); and (3) the Insubric Trapa stands are old as many of them were known already at the beginning of 19th century (Supporting Information, Table S4). Old demes of pond-dwelling organisms can be genetically less differentiated than younger demes because they experience more immigration over time (Haag et al., 2005).

In summary, the finding that the Insubric Trapa stands do not show the strongly reduced genetic diversity and increased genetic differentiation found in some other annual aquatic plants may be explained by their large census populations, their old age and the permanence of their habitat (Pannell \& Charlesworth, 2000; Haag et al., 2005).

\section{DISTRIBUTION HISTORY}

Our analysis of the distribution history of Insubric Trapa revealed that $c .52 \%$ of the reported water chestnut stands have gone extinct since the beginning of the 19th century (Fig. 1). The species completely disappeared from the Swiss part of the Insubric region, where six localities were documented between 1824 and c. 1970. Seventeen stands were known from the Italian part, of which 11 still exist today (Fig. 1; Supporting Information, Table S4). During the 19th century, Insubric water chestnuts inhabited diverse freshwater habitats: besides shallow lakes, they colonized deep lake bays and small water bodies such as ponds and ditches of the wetlands adjacent to the large lakes (e.g. Comolli, 1834; Franzoni, 1888; Supporting Information, Table S4).

The causes for local extinctions are only rarely reported. One wetland stand disappeared due to a heavy flood in the mid-1800s (Schröter, 1899). The unique population of T. muzzanensis of Lake Muzzano went extinct towards the end of the 1960 s after $c$. 40 years of anthropogenic hypereutrophication (Larocque-Tobler \& Pla-Rabès, 2015). According to Schinz (1907), the population of T. muzzanensis was already declining before this, apparently due to overharvesting of fresh plants by botanists, as the small Lake Muzzano harboured the only stand of this taxon in Central Europe. 


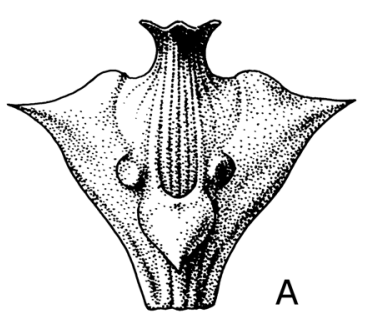

A

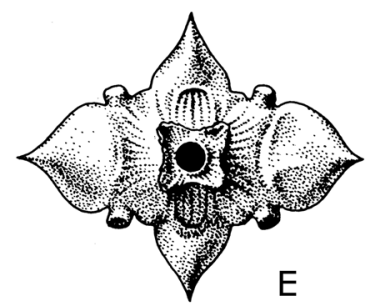

E
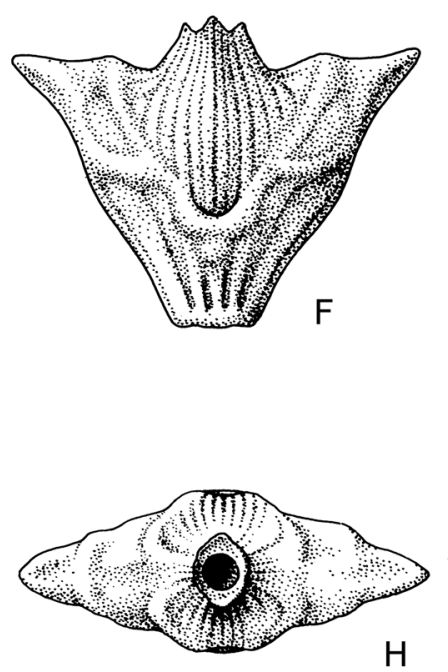

$\mathrm{H}$
B

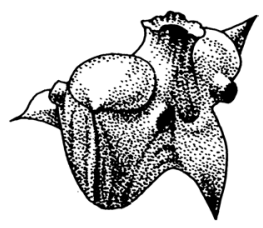

C

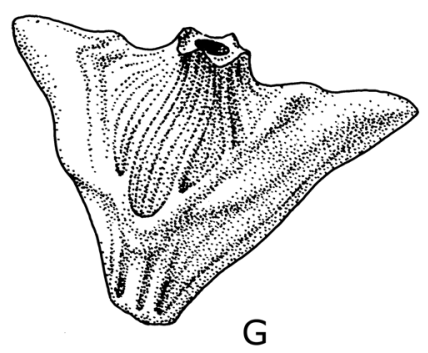

$1 \mathrm{~cm}$

Figure 6. Scientific drawings of nuts of Trapa muzzanensis from lake Muzzano (A-E) (Accession No. ZM-00009090; Leg. A. Bettelini; around 1900) and Trapa verbanensis from lake Verbano (Angera) (F-H) [ZM (no accession number); Leg. J. Bär; 18 May 1908]. Discriminating characteristics between T. natans and T. muzzanensis are the four 'tubercules' between the horns (E) and the absence of the two lower horns in T. verbanensis, respectively.

\section{PHYLOGENETIC POSITION OF INSUBRIC TRAPA}

Our ITS analyses revealed that two ribotypes of T. natans s.l. occurred in the Insubric region, one of which went extinct during the 20 th century (Table 1 ). The extinct ribotype was found only in a museum specimen determined as T. muzzanensis, which was sampled at its locus classicus (Lake Muzzano), in 1961 (Table 1). In line with the original description of that taxon, the morphometric analysis revealed subtle but consistent differences between nuts from Lake Muzzano (taken from herbaria and fruit collections) and T. natans nuts from other lakes (Fig. 5). Thus, assigning the genetically and morphologically distinct
Muzzano population to a separate taxon may seem justified. However, to thoroughly evaluate its taxonomic status, an assessment of the genetic and morphological variability of $T$. natans across its entire distribution range is needed. Clearly, T. muzzanensis cannot be regarded as a locally endemic lineage since the ribotype was also found in the sample from Sri Lanka (Figs 3, 4). Moreover, T. muzzanensis nut types were also found in Eastern Europe, in the floodplains of Drava river and the Danube delta, in the floodplains of the Berezina and Dnepr rivers and in the floodplains of Oka river and the Volga delta (Gams, 1927; Tzvelev, 1993; Ciocârlan, 2011). 
Samples from Lake Verbano, the only lake harbouring T. verbanensis in the Insubric region, did not have a distinct ribotype (Table 1; Figs 3, 4). This finding contrasts with the constant and uniform nut morphology found in that lake (Fig. 5). Although the nut characteristics fall within the morphological variability of T. natans and may therefore be an expression of phenotypic plasticity within a single species rather than a sign of reproductive isolation, the low genetic resolution found in the ITS sequences does not allow for an evaluation of this taxon.

Although the genetic resolution of ITS sequences was low, our findings suggest that the currently simplified taxonomy of Trapa in Europe may not capture the actual genetic diversification, which could lead to Linnean shortfalls and biased Red List classifications in this genus (Kozlowski, 2008).

\section{CONSERVATION IMPLICATIONS}

Preserving large census populations is important because mean fitness of local Insubric water chestnut stands may be lowered due to inbreeding since selfpollination appears to occur frequently in this species (Kadono \& Schneider, 1986; Arima et al., 1999). Should these large stands become small, levels of genetic drift will increase. This would not only result in the loss of neutral genetic diversity, but could also lead to the fixation of deleterious mutations, which would reduce fitness and could ultimately increase extinction risk (e.g. Ellstrand \& Elam, 1993; Frankham et al., 2014; Lohr \& Haag, 2015).

Maintaining large local T. natans populations is even more important because $c .52 \%$ of the reported Insubric water chestnut stands have disappeared since the 19th century, which suggests an increasing fragmentation of the Insubric T. natans population and an increasing isolation of local stands. This process is paralleled by the abandonment of the use by humans of Trapa fruits as a wild crop, pig fodder and rosaries in the southern Alps, which may have assisted in the dispersal of the species in the past (Comolli, 1834; Jäggi, 1883). Hence, part of the low genetic structuring found in Insubria may be explained not only by the low levels of genetic drift but also by higher levels of gene flow due to occasional human-mediated dispersal (e.g. Roman \& Darling, 2007).

Large and dominant $T$. natans stands have been associated with anthropogenic eutrophication especially outside the native range of the species, where it is considered invasive (Hummel \& Kiviat, 2004). Similarly, in the Insubric region, all large water chestnut stands are currently growing in shallow and eutrophic lakes (LIMNO, 2017). Such stands can obstruct the use of water surfaces in some lakes and are therefore mowed by freshwater managers (M. Alessi, pers. observ.). Although the species appears resistant or even profits from certain levels of eutrophication (Apinis, 1940; Hummel \& Kiviat, 2004), prolonged hyper-eutrophication can lead to its extinction (Larocque-Tobler \& Pla-Rabès, 2015). Improving the water quality by reducing anthropogenic eutrophication should therefore favour the survival of the species, at the same time reducing excessive growth and the necessity to mow Trapa stands.

\section{ACKNOWLEDGEMENTS}

We thank Christiane Jacquat for her help with the nut collection of the Botanical Museum of the University of Zurich (ZM); Reto Nyffeler and Josefine Jacksch $(\mathrm{Z}+\mathrm{ZT})$, Gabriele Galasso (MSNM), Chiara Nepi and Lorenzo Cecchi (FI) and Sofia Mangili (LUG) for help with the herbarium specimens; Natalia Rehush for the translation of Russian publications; Christine Matter for help with the literature; Mr Simonazzi for sampling the Mantua population; the land owners and managers of nature reserves for providing access to lakes; Michele Abderhalden for GIS support; Michael Jutzi for Info Flora data bank extraction; Patrik Mràz for help with statistical analysis; Rosario Mosello and Piero Guilizzoni for kindly sharing data; Robert Home and Chris Young for help with the manuscript; Ruth Baur for the scientific drawings; and two anonymous reviewers for their helpful comments.

\section{REFERENCES}

Akaike H. 1973. Maximum likelihood identification of Gaussian autoregressive moving average models. Biometrika 60: $255-265$.

Apinis AE. 1940. Untersuchungen über die Ökologie der Trapa L. II Teil. Bedingungen der Keimung und Entwicklung der Pflanze. Acta Horti Botanici Universitatis Latviensis 13: 84-145.

Apinis AE. 1967. Trapa natans L. als Klima-und Sukzessionszeiger. In: Tüxen R, ed. Pflanzensoziologie und palynologie. The Hague: Junk, 14-23.

Arcangeli G. 1882. Compendio della flora italiana; ossia, manuale per la determinazione delle piante che trovansi selvatiche od inselvatichite nell'Italia e nelle isole adiacenti. Turin: E. Loescher.

Arima S, Daigoho M, Hoque A. 1999. Flower development and anthesis behavior in the water chestnut (Trapa sp.). Bulletin of the Faculty of Agriculture, Saga University 84: 83-92.

Arrigo N, Buerki S, Sarr A, Guadagnuolo R, Kozlowski G. 2011. Phylogenetics and phylogeography of the monocot genus Baldellia (Alismataceae): Mediterranean refugia, suture zones and implications for conservation. Molecular Phylogenetics and Evolution 58: 33-42. 
Barrett SC, Eckert CG, Husband BC. 1993. Evolutionary processes in aquatic plant populations. Aquatic Botany 44: 105-145.

Bonin A, Bellemain E, Bronken Eidesen P, Pompanon F, Brochmann C, Taberlet P. 2004. How to track and assess genotyping errors in population genetics studies. Molecular Ecology 13: 3261-3273.

Chenevard P. 1910. Catalogue des plantes vasculaires du Tessin. Geneva: Kündig, 345.

Chessel D, Dufour AB, Thioulouse J. 2004. The ade4 package - I: one-table methods. $R$ News 4: 5-10.

Ciocârlan V. 2011. Vascular flora of the Danube Delta. Analele Stiintifice Ale Universitatii Al Cuza Iasi 57: 41-64.

Clement M, Posada D, Crandall KA. 2000. TCS: a computer program to estimate gene genealogies. Molecular Ecology 9: 1657-1659.

Comolli G. 1824. Plantarum a Josepho Comollio M. D. in Lariensi provincia lectarum enumeratio, quam ipse in botanophilorum usu atque commodo exhibet uti prodromum Florae comensis. Novo-Comi: ex tipographia C. Petri Ostinelli.

Comolli G. 1834. Flora Comense: disposta secondo il sistema di Linneo. Como: Ostinelli.

Conti E, Litt A, Wilson PG, Graham SA, Briggs BG, Johnson LAS, Sytsma KJ. 1997. Interfamilial relationships in Myrtales: molecular phylogeny and patterns of morphological evolution. Systematic Botany 22: 629-647.

Darriba D, Taboada GL, Doallo R, Posada D. 2012. jModelTest 2: more models, new heuristics and parallel computing. Nature Methods 9: 772.

Dudgeon D, Arthington AH, Gessner MO, Kawabata Z, Knowler DJ, Lévêque C, Naiman RJ, Prieur-Richard AH, Soto D, Stiassny ML, Sullivan CA. 2006. Freshwater biodiversity: importance, threats, status and conservation challenges. Biological Reviews 81: 163-182.

Eckert CG, Lui K, Bronson K, Corradini P, Bruneau, A. 2003. Population genetic consequences of extreme variation in sexual and clonal reproduction in an aquatic plant. Molecular Ecology 12: 331-344.

Ehrich D. 2006. AFLPdat: a collection of R functions for convenient handling of AFLP data. Molecular Ecology Notes 6: 603-604.

Elansary H, Adame L, Štorchová H. 2010. Uniformity of organellar DNA in Aldrovanda vesiculosa, an endangered aquatic carnivorous species, distributed across four continents. Aquatic Botany 92: 214-220.

Ellstrand NC, Elam DR. 1993. Population genetic consequences of small population size: implications for plant conservation. Annual Review of Ecology, Evolution and Systematics 24: 217-242.

Evanno G, Regnaut S, Goudet J. 2005. Detecting the number of clusters of individuals using the software STRUCTURE: a simulation study. Molecular Ecology 14: 2611-2620.

Excoffier L, Smouse PE, Quattro JM. 1992. Analysis of molecular variance inferred from metric distances among DNA haplotypes: application to human mitochondrial DNA restriction data. Genetics 131: 479-491.

Flerov AT. 1926. De genere Trapa L. Izvestija Botaniceskogo Sada Akademii Nauk SSSR 24: 13-45. [in Russian]
Frankham R, Bradshaw CJ, Brook BW. 2014. Genetics in conservation management: revised recommendations for the 50/500 rules, Red List criteria and population viability analyses. Biological Conservation 170: 56-63.

Franzoni A. 1888. Le piante fanerogame della Svizzera Insubrica enumerate secondo il metodo decandolliano. Per cura di Alberto Franzoni; opera postuma ordinata e annotata dal Dr. A. Lenticchia. Zurich: Zürcher \& Furrer, 88.

Gams H. 1927. Die Gattung Trapa L. Die Pflanzenareale; Reihe 1, Heft 3, Karte 21-30. Jena: Fischer, 39-41.

Gascuel O. 1997. BIONJ: an improved version of the NJ algorithm based on a simple model of sequence data. Molecular Biology and Evolution 14: 685-695.

Guindon S. 2009. PhyML - manual, version 3.0. Available at: www.atgc-montpellier.fr (Accessed 6 January 2015).

Guindon S, Dufayard JF, Lefort V, Anisimova M, Hordijk W, Gascuel O. 2010. New algorithms and methods to estimate maximum-likelihood phylogenies: assessing the performance of PhyML 3.0. Systematic Biology 59: 307-321.

Haag CR, Riek M, Hottinger JW, Pajunen VI, Ebert D. 2005. Genetic diversity and genetic differentiation in Daphnia metapopulations with subpopulations of known age. Genetics 170: 1809-1820.

Hegi G. 1926. Illustrierte Flora von Mitteleuropa. Mit besonderer Berücksichtigung von Deutschland, Oesterreich und der Schweiz. Zum Gebrauche in den Schulen und zum Selbstunterricht. V. Band, 2. Teil. Munich: Lehmanns Verlag, 882-890.

Hoque A, Anai T, Arima S. 2005. Analysis of molecular diversity in water chestnut based on RAPD markers. Biotechnology 4: 144-148.

Hoque A, Davey MR, Arima S. 2009. Water chestnut: potential of biotechnology for crop improvement. Journal of New Seeds 10: 180-195.

Hřibová E, Čížková J, Christelová P, Taudien S, de Langhe E, Doležel J. 2011. The ITS1-5.8S-ITS2 sequence region in the Musaceae: structure, diversity and use in molecular phylogeny. PLoS One 6: e17863.

Hummel M, Kiviat E. 2004. Review of world literature on water chestnut with implications for management in North America. Journal of Aquatic Plant Management 42: 17-27.

Hussner A. 2012. Alien aquatic plant species in European countries. Weed Research 52: 297-306.

Info Flora. 2014. Swiss National Flora Databank. Available at: www.infoflora.ch (Accessed 6 November 2014).

Jäggi J. 1883. Die Wassernuss (Trapa natans L.) und der Tribulus der Alten. Neujahrsschrift der Naturforschenden Gesellschaft in Zürich. Zurich: Zürcher und Furrer.

Kadono Y. 1987. A preliminary study on the variation of Trapa in Japan. Acta Phytotaxonomica et Geobotanica 38: 199-210.

Kadono Y, Schneider EL. 1986. Floral biology of Trapa natans var. japonica. The Botanical Magazine 99: 435-439.

Kim C, Na HR, Choi HK. 2010. Molecular genotyping of Trapa bispinosa and T. japonica (Trapaceae) based on nuclear AP2 and chloroplast DNA trnL-F region. American Journal of Botany 97: 149-152. 
Kozlowski G. 2008. Is the global conservation status assessment of a threatened taxon a utopia? Biodiversity and Conservation 17: 445-448.

Lansdown R. 2013. Trapa natans. The IUCN Red List of Threatened Species 2013. Available at: www.iucnredlist.org (Accessed 11 March 2016).

Larocque-Tobler I, Pla-Rabès S. 2015. Using paleolimnology to find restoration solutions: the case of Lake Muzzano, Switzerland. Frontiers in Ecology and Evolution 3: 70.

Li XL, Fan XR, Chu HJ, Li W, Chen YY. 2017. Genetic delimitation and population structure of three Trapa taxa from the Yangtze River, China. Aquatic Botany 136: 61-70.

LIMNO. 2017. Database della qualità dei laghi italiani. Available at: www.ise.cnr.it/limno (Accessed 1 May 2017).

Lohr JN, Haag CR. 2015. Genetic load, inbreeding depression, and hybrid vigor covary with population size: an empirical evaluation of theoretical predictions. Evolution 69: 3109-3122.

Mona S, Ray N, Arenas M, Excoffier L. 2014. Genetic consequences of habitat fragmentation during a range expansion. Heredity 112: 291-299.

McCauley DE, Raveill J, Antonovics J. 1995. Local founding events as determinants of genetic structure in a plant metapopulation. Heredity 75: 630-636.

Nei M. 1987. Molecular evolutionary genetics. New York: Columbia University Press.

De Notaris G. 1876. Due nuove specie di piante Italiane, descritte nel catalogo dei semi dell'orto botanico di Roma, diretto dal prof De Notaris. Nuovo Giornale Botanico Italiano; e Bollettino della Società Botanica Italiano 8: 42.

Nybom H. 2004. Comparison of different nuclear DNA markers for estimating intraspecific genetic diversity in plants. Molecular Ecology 13: 1143-1155.

Pannell JR, Charlesworth B. 2000. Effects of metapopulation processes on measures of genetic diversity. Philosophical Transactions of the Royal Society of London B: Biological Sciences 355: 1851-1864.

Paradis E, Claude J, Strimmer K. 2004. APE: analyses of phylogenetics and evolution in $\mathrm{R}$ language. Bioinformatics 20: 289-290.

Pritchard JK, Stephens M, Donnelly P. 2000. Inference of population structure using multilocus genotype data. Genetics 155: 945-959.

R Core Team. 2014. $R$ : a language and environment for statistical computing. Vienna: R Foundation for Statistical Computing. Available at: https://www.r-project.org/

Reisch C. 2007. Genetic structure of Saxifraga tridactylites (Saxifragaceae) from natural and man-made habitats. Conservation Genetics 8: 893-902.

Reisch C, Bernhardt-Römermann M. 2014. The impact of study design and life history traits on genetic variation of plants determined with AFLPs. Plant Ecology 215: 1493-1511.

Renfrew C. 1973. Palaeoethnobotany: the prehistoric food plants of the Near East and Europe. New York: Columbia University Press.

Rogers SO, Bendich AJ. 1994. Extraction of total cellular DNA from plants, algae and fungi. In: Gelvin SB, ed. Plant molecular biology manual. Dordrecht: Springer, 183-190.
Roman J, Darling JA. 2007. Paradox lost: genetic diversity and the success of aquatic invasions. Trends in Ecology \& Evolution 22: 454-464.

Santamaría L. 2002. Why are most aquatic plants widely distributed? Dispersal, clonal growth and small-scale heterogeneity in a stressful environment. Acta Oecologica 23: 137-154.

Schinz H. 1907. Trapa natans L. in der Schweiz und in Oberitalien. Vierteljahresschrift der Naturforschenden Gesellschaft Zürich 52: 474-483.

Schröter C. 1899. Contribution à l'étude des variétés de Trapa natans L. Archives des Sciences Physiques et Naturelles 8: 441-452.

Strayer DL, Dudgeon, D. 2010. Freshwater biodiversity conservation: recent progress and future challenges. Journal of the North American Benthological Society 29: 344-358.

Steiner H. 1912. Das Plankton und die makrophytische Uferflora des Luganersees. Leipzig: Klinhardt.

Stöver BC, Müller KF. 2010. TreeGraph 2: combining and visualizing evidence from different phylogenetic analyses. BMC Bioinformatics 11: 7.

Takano A, Kadono Y. 2005. Allozyme variations and classification of Trapa (Trapaceae) in Japan. Aquatic Botany 83: 108-118.

Tamura K, Stecher G, Peterson D, Filipski A, Kumar S. 2013. MEGA6: Molecular Evolutionary Genetics Analysis version 6.0. Molecular Biology and Evolution 30: 2725-2729.

Tutin TG. 1968. Trapa. In: Tutin TG, Heywood VH, Burges NA, Moore DM, Valentine DH, Walters SM, Webb DA, eds. Flora Europaea 2. Cambridge: Cambridge University Press, 303.

Tzvelev NN. 1993. De genere Trapa L. (Trapaceae) in Europa orientali et Asia Boreali. Novosti Sistematiki Vysshikh Rastenii 29: 99-107. [in Russian]

Untergasser A, Cutcutache I, Koressaar T, Ye J, Faircloth BC, Remm M, Rozen SG. 2012. Primer3 - new capabilities and interfaces. Nucleic Acids Research 40: e115.

Vasilev VN. 1974. Family CXIV. Hydrocaryaceae Raimann. In: Shishkin BK, Bobrov EG, eds. Flora of the U.S.S.R. Volume XV. Malvales, Parietales, Myrtiflorae. Jerusalem: Israel Program for Scientific Translations, 477-495.

Voigt A. 1921. Beiträge zur Floristik des Tessins. II. Abhandlungen der Naturwissenschaftlichen Gesellschaft ISIS in Dresden 1920/1921: 12-19.

Vos P, Hogers R, Bleeker M, Reijans M, van de Lee T, Hornes M, Frijters A, Pot J, Peleman J, Kuiper M. 1995. AFLP: a new technique for DNA fingerprinting. Nucleic Acids Research 23: 4407-4414.

Walser B, Haag CR. 2012. Strong intraspecific variation in genetic diversity and genetic differentiation in Daphnia magna: the effects of population turnover and population size. Molecular Ecology 21: 851-861.

White TJ, Bruns T, Lee S, Taylor JW. 1990. Amplification and direct sequencing of fungal ribosomal RNA genes for phylogenetics. In: Innis MA, Gelfand DH, Sninsky JJ, White TJ, eds. PCR protocols: a guide to methods and amplifications. San Diego: Academic Press, 315-322.

Young A, Boyle T, Brown T. 1996. The population genetic consequences of habitat fragmentation for plants. Trends in Ecology \& Evolution 11: 413-418. 


\section{SUPPLEMENTARY MATERIAL CAPTIONS}

Additional Supporting Information may be found in the online version of this article at the publisher's web-site:

Table S1. Details of herbarium specimens used for the ITS analysis.

Table S2. Details of nuts used for the morphometric study.

Table S3. Univariate statistics of continuous quantitative nut characters for taxa and sampling sites.

Table S4. Distribution records and habitat characteristics of extinct and current stands.

Table S5. Substitutions and indels in the ITS1-5.8S rRNA-ITS2 ribotypes.

Table S6. Eigenvector values of traits measured on nuts.

Figure S1. Results of 100 STRUCTURE runs.

Figure S2. Ten STRUCTURE bar plots illustrating the proportion of membership of each of the 72 individuals to the four inferred genetic clusters. 